\title{
Pregnancy in a Obese Married Lady with Hyperprolactinemia, Severe Hypertension Mildly Raised ACTH with Symptomatic Treatment Like Topiramate, Caberlin, Labetolololand Cycle Correction- Live Healthy Baby
}

\author{
Kulvinder Kochar Kaur ${ }^{1 *}$, Gautam Allahbadia ${ }^{2}$ and Mandeep Singh ${ }^{3}$ \\ ${ }^{1}$ Dr Kulvinder Kaur Centre for Human Reproduction, India \\ ${ }^{2}$ Rotunda-A Centre for Human reproduction, India \\ ${ }^{3}$ Swami Satyanand Hospital, India
}

Submission: March 30, 2017; Published: May 10, 2017

*Corresponding author: Kulvinder Kaur, Scientific Director, Dr Kulvinder Kaur Centre for Human Reproduction, India, Fax: 91-181-4613422, Tel:

91-181-9501358180; Email: kulvinder.dr@gmail.com

\section{Case Report}

A 29 year old patient married for 5 years presented with irregular cycles, obesity and primary infertility of 5 years. On examination she was hypertensive with BP 190/110mm HG, Ht$180 \mathrm{~cm}, \mathrm{Wt}-120 \mathrm{~kg}$ BMI, $37.3 \mathrm{Kg} / \mathrm{m}^{2}$ SFSH- $6.2 \mathrm{iu} / \mathrm{l}, \mathrm{LH}-9.2 \mathrm{IU} / \mathrm{L}$, S prolactin- $191 \mathrm{ng} / \mathrm{ml}(5-29 \mathrm{ng} / \mathrm{ml})$, Thyroid function test was normal, s.cortisol-5(wnl), SDHES-WNL, GTT-within normal limits, postprandial insulin $56 \mathrm{u}-\mathrm{wnl}, \mathrm{s}$ testosterone was $0.6 \mathrm{ng} /$ $\mathrm{ml}(0.2-0.8 \mathrm{ng} / \mathrm{ml})$. ACTH was increased to $56 \mathrm{pu} / \mathrm{ml}$. Hence low dose and high dose dexamethasone suppression was done which was within normal limits. Ultrasonography showed bilateral polycystic ovaries and normal sized uterus, MRI Brain was done to rule out a microadenoma/macroadenoma although none found, MRI - showed empty sella without any adenoma. Patient was treated with topiramate $50 \mathrm{mg}$ bd for weight control, Caberlin $0.5 \mathrm{mg}$ twice weekly for prolactin control, labetolol $100 \mathrm{mg}$ hs for hypertension and to avoid pregnancy and control of cycles till weight control and prolactin control obtained lynoral $0.05 \mu \mathrm{gx} 25$ days with medroxy progesterone acetate in latter half of cycles $x$ 10 days but surprisingly patient conceived on this treatment and hence to avoid any teratogenic effects topiramate and caberlin were omitted. BP remained controlled on labetolol till latter part of pregnancy when it rose and patient developed IUGR when elective LSCS was done and a live male baby weighing $2 \mathrm{~kg}$ was born with a good apgar score. Unfortunately baby developed retention of stools when lower intestinal atresia was diagnosed and was operated upon after which baby remained ok and grew normally (Figure 1).

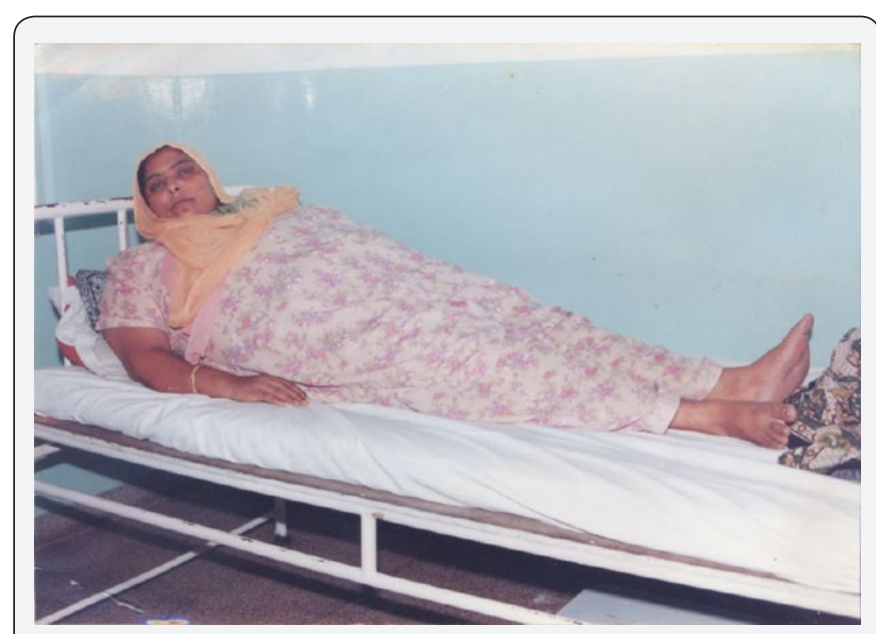

Figure 1: obese with hyperprolactinemia.

\section{Discussion \& Conclusion}

Normally topiramate has been associated with spontaneous conceptions in severe obesity [1]. Similarly caberline treatment has been associated with prolactin control and spontaneous conceptions in prolactioma or simple hyperprolactijnemia [2]. Surprisingly addition of lynoral (ethinyl estradiol) and deviry (medroxy- progesterone acetate) meant for inhibition of ovulation before topiramate and caberline could be omitted caused pregnancy possibly by overcoming the negative feedback due to hyperprolactinemia. Getting markedly obese patient with multiple problems is quiet difficult as ovulation induction 
requires heavy doses of gonadotropins. Although patient conceived the baby developed small intestinal atresia, which got corrected. This is a rare case of an obese hypertensive, severe hyperprolactinemic patient having, raised ACTH along with conceiving on specific treatment of topiramate, caberline, labetolol and 3 months of lynoral/deviry given for control of cycles.

\section{Refernces}

1. Kochar Kaur Kulvinder, Allahbadia GN, Singh Mandeep (2007) Topiramate-a novel drug in aiding ovulation induction (OI) in extremely obese PCOS patients resistant to any kind of Ovulation Induction.

2. Kulvinder Kaur, Singh Mandeep, SPS Virk (2003) Prolactinomas in Infertility. Reviews in Gynaecological Practice 3: 180-183.

Your next submission with Juniper Publishers will reach you the below assets

- Quality Editorial service

- Swift Peer Review

- Reprints availability

- E-prints Service

- Manuscript Podcast for convenient understanding

- Global attainment for your research

- Manuscript accessibility in different formats ( Pdf, E-pub, Full Text, Audio)

- Unceasing customer service

Track the below URL for one-step submission https://juniperpublishers.com/online-submission.php 